\title{
ENVIRONMENTAL PROTECTION AS AN OBSTACLE TO FREE MOVEMENT OF GOODS: REALIST JURISPRUDENCE IN ARTICLES 28 AND 30 OF THE E.C. TREATY
}

Eric Engle, JD, DEA, LLM*

\begin{abstract}
Free trade and environmental protection are two norms that sometimes collide. The resolution of colliding norms can occur either using a formalist "descriptive" analysis, or using a "prescriptive" approach of legal realism. It may seem intuitive to imagine realism and formalism as mutually exclusive. However, this dualism is not entirely accurate. The realist-formalist dualism is unsatisfying because legal realism critiques the capricious nature of formalism only to replace it with likewise capricious methods of legal decision-making. Further, courts sometimes act as realists and at other times as formalists. Finally, many methods of legal interpretation may be considered either "formalist" or "realist."

This paper examines the conflict between free trade and environmental protection in E.C. law. It uses Articles 28 and 30 of the E.C. Treaty as a foil with which to draw out the distinctions and limits of both realism and formalism. A formal analysis of Articles 28 and 30 of the E.C. Treaty reveals a series of cases that struggle first to define waste as wares and then to determine the limitations that the free movement of goods imposes on environmental standards and vice versa. However, this unsatisfying formal analysis is not the only possible interpretation of the case law arising out of Articles 28 and 30. An analysis based on legal realism is also possible but not entirely satisfying. This paper concludes that the realist-formalist dualism, though tenable, does not solve the problem of capricious legal power.
\end{abstract}

* $\quad$ Eric Engle, JD (St. Louis), DEA (Paris II), LLM, Dr.Jur. (Bremen), maintains a personal website and his other writings are available at: http://ssrn.com/author=879868. 


\section{Table of Contents}

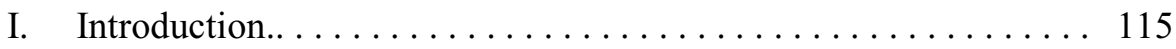

A. Formalism. ........................ 117

B. Legal Realism. ....................... 118

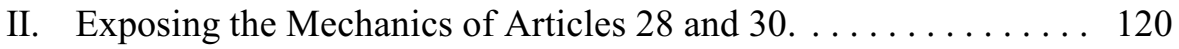

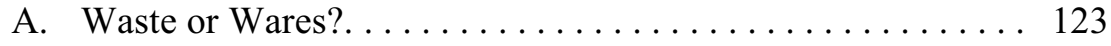

1. Comm'n v. Kingdom of Denmark ("Danish Bottles"). . . 123

2. Walloon Waste. ......................... 127

B. Recycling_-Oil Cases: Inter Huiles; Brûleurs d'Huiles Usagées.......................... 130

C. Criminal Cases Involving the Free Movement of Wastegoods. . . . . . . . . . . . . . . . . . . . . . . . . 131

1. Waste Dumping Criminal Proceedings against Matteo Peralta. ...................... 131

2. Criminal Proceedings v. Euro Tombesi.......... 132

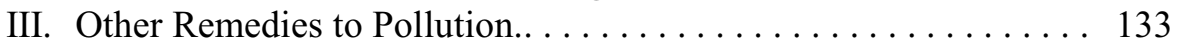

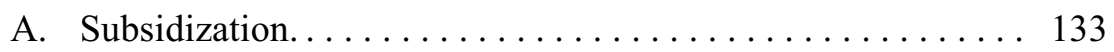

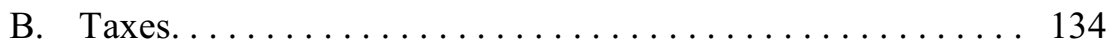

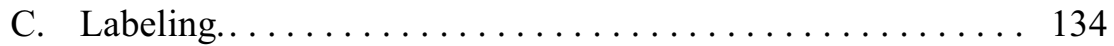

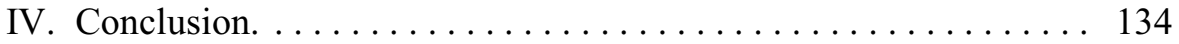




\section{INTRODUCTION}

The European Community recognizes four fundamental freedoms as central to the Community's existence: the free movement of goods, the free movement of labor, the free movement of capital, and the right of businesses to establish anywhere in the Union. ${ }^{1}$ These four freedoms were, and are, the cornerstones of the European edifice, one of the world's largest single markets. The extent of these four freedoms explains why the E.U. has always been more than a mere customs union. Obviously, these four freedoms are central to the formation of the single European market. There has simply been no legal development more important in the past century than the creation of a single European market because free trade contributes to peace by making war unprofitable.

This paper will examine the limitations to the free movement of goods in the interest of environmental protection in the law of the European Union. It will analyze this conflict of norms through the lenses of legal realism and formalism. Legal realism is a theory that was developed in the United States and by Scandinavians publishing primarily in English. ${ }^{2}$ It has had little overt impact outside the United States. However, this article argues that realist thinking has had an indirect affect overseas and uses E.U. law to illustrate that point.

Article 28 (ex-Article 30) of the E.C. Treaty guarantees the free movement of goods and services. ${ }^{3}$ However, Article 30 (ex-Article 36) provides exceptions to that rule: the free movement of goods and services may be limited for reasons of public safety, health, and well-being. ${ }^{4}$ Articles 28 and

1. Treaty Establishing the European Community, Mar. 25, 1957, 298 U.N.T.S. 11, as amended by Treaty of Amsterdam, Oct. 2, 1997, 1997 O.J. (C 340) 1, as amended by Treaty of Nice, Feb. 26, 2001, 2001 O.J. (C 80) 1, consolidated version reprinted in 2002 O.J. (C 325) 33 [hereinafter E.C. Treaty].

2. See, e.g., Alf Ross, Towards a Realistic Jurisprudence: A Criticism of the Dualism in Law (E. Munksgaard 1946); Alf Ross, "Tĥ-Tû", 70 Harv. L. Rev. 812 (Mar. 1957); Karl Olivecrona, LAW AS FACT (Oxford University Press 1939).

3. E.C. Treaty, supra note 1, art. 28 reads in its entirety: "Quantitative restrictions on imports and all measures having equivalent effect shall be prohibited between Member States."

4. E.C. Treaty, supra note 1, art. 30 reads in its entirety:

The provisions of Articles 28 and 29 shall not preclude prohibitions or restrictions on imports, exports or goods in transit justified on grounds of public morality, public policy or public security; the protection of health and life of humans, animals or plants; the protection of national treasures possessing artistic, historic or archaeological value; or the protection of industrial and commercial property. Such prohibitions or restrictions shall not, however, constitute a means of arbitrary discrimination or a disguised restriction on trade between Member States. 
30 of the E.C. Treaty are critical to the free movement of goods since they set out the existence of that freedom and some of the principal limitations on it. Article 28 is often litigated not only because individual economic actors have an important interest in terms of trade, but also because free trade is central to the European Communities. ${ }^{5}$ For this reason, in this paper, we can only examine one particular aspect of a much broader legal landscape, the nexus between trade law (especially E.U. trade law) and legal theory. However, this one aspect likely is representative of the type of problems both within the E.C. Treaty and within legal theory.

The rule/exception schema of Articles 28 and 30 is a reflection of a larger trend in law generally - the relativization of rights. Rights today are no longer seen as absolute, but are almost always relativized by other rights or through exceptions to the general rule. ${ }^{6}$ This relativization of rights occurs in the law as a result of legal realism and as a reflection of a general epistemological trend in all fields of thought toward relativization in the 1900's that still influences courts today. We will see that European courts, like their U.S. counterparts, usually "hedge" and leave open "back-doors" in their decisions. These hedges include not only judicial parsimony-deciding as few issues as necessary - and judicial economy — solving those issues with as few judicial resources as possible — but also outright hedging — leaving "outs" for future courts to avoid or distinguish the precedent of the instant court's decision. If a court acknowledges a right, it reminds the reader that the right is not absolute, allowing that court or future courts to avoid being bound by that case. This can be seen in a case analyzed later in this article, Brûleurs d'Huiles Usagées. In that case the European Court of Justice ("ECJ"-the Brussels Court) points out that the free movement of goods is not an absolute right. ${ }^{7}$ Relativization of rights brings us to the central theoretical topic of this paper, the relationship between legal realism and formalism.

What is formalism?

5.

Every State is a community of some kind, and every community is established with a view to some good; for mankind always act in order to obtain that which they think good. But, if all communities aim at some good, the state or political community, which is the highest of all, and which embraces all the rest, aims at good in a greater degree than any other, and at the highest good.

Aristotle, Politics, Book 1, $\uparrow 1$ (Benjamin Jowett trans., Clarendon Press 1926). (I.e., the State is the means to the end of the good life.)

6. Joseph Jenkins, Heavy Law/Light Law: Walter Benjamin, Friedrich Nietzsche, Robert Bork, Duncan Kennedy, 17 Cardozo Stud. L. \& Lit. 249, 261-62 (2005).

7. Case C-240/83, Procureur de la Republique v. Ass'n de Defense des Bruleurs d'Huiles Usagees, 1985 E.C.R. I-531 ("The principle of free trade is not to be viewed in absolute terms."). 


\section{A. Formalism}

Historically, legal analysis rested on the logic that contemporary scholars call formalism. Formalism is the teleologically blind application of logical categories to law that elevate form and procedure over substantive outcomes in order to determine the law in a supposedly objective manner. ${ }^{8}$ Formalist analysis relies on a search for legislative intent, textual analysis, and bright line tests such as: ejusdem generis, expressio unius est exclusio alterius, and lex posteriori. The problem is, legislative intent may not be determinable. Privileging syntax over semantics and ignoring teleology can lead to substantively unfair outcomes. This abuse of the law may result either 1) accidentally; by ignoring teleology; by privileging syntax, form over substance, and semantics; or 2) intentionally, via a calculating manipulation that substitutes the individual and subjective will of the judge for that of the collective's legislature. Abuse of the law is possible. With a bit of creativity, one can always find a legal text, a general principle, or a Latin maxim to support either a restrictive interpretation (exceptio est strictissimae interpretationis) or an open ended interpretation (generalia specialibus non derogant $)^{9}$ to justify either finding or refusing to find an exception to any given general rule.

Formalism can be used to manipulate legal outcomes by applying those contradictory principles that purport to coexist in the overall legal system without contradiction. Either one must decide that the principles are not contradictory and develop and deploy an entire jurisprudence to rationalize them, or one must recognize the contradictions. At that point a second choice arises. Either one must expose the contradictions or exploit them. If one sees the contradictions and knows how to exploit them, one has a strong incentive to cover them up. Formalism cannot develop a powerful critique of itself within its own terms because formalists are either naïve or cynical. Moreover, the iconoclastic solution of exposing the contradictions in formalism feeds the cynics view of law as an instrument to be used to aggrandize power. Perhaps worst of all, exposing the hypocrisy of the existing system in no way

8. Richard A. Posner, Legal Formalism, Legal Realism, and the Interpretation of Statutes and the Constitution, 37 CASE W. Res. L. Rev. 179, 181 (1987) (defining legal formalism as "the use of deductive logic to derive the outcome of a case from premises accepted as authoritative").

9. See, e.g., Peter Underwood, Statutory Interpretation, http://www.law.uts.edu.au/ peteru/ lph/f6931.htm (last visited 2004). The influence of Professor John Griesbach, who pointed this out to me and encouraged my theoretical penchant, must also be noted. 
guarantees the justice of some other system that should presumably replace it. We must identify a problem correctly to solve it. However, merely identifying a problem does not solve it. The only way out of this game is to propose some other, more objective and fair system of legal interpretation. Realism tried to do this, but was unsuccessful in this author's opinion.

What is legal realism?

\section{B. Legal Realism}

In its milder variant, legal realism argues that we should look at what judges do, and not what they say. ${ }^{10} \mathrm{We}$ should consider the psychological and institutional forces that inform judges and shape their opinions. In its wilder variant, realism is a form of antinomianism. ${ }^{11}$ The law is seen as a smokescreen for power intended to rationalize its operations. ${ }^{12}$ This article will look at a small sample of law in the European Union to test whether realism can bring insights into the actual decisions of the Court in Brussels.

The heart of the realist critique of formalism is that law is not in fact as rigid as formalism proposes or interprets. ${ }^{13}$ For realists (like postmodernists), ${ }^{14}$ law is inevitably indeterminate. ${ }^{15}$ Realists would argue that the law is, and should be flexible and adaptive. That flexibility permits the system to survive. However, flexibility also belies, undermines, and denies the supposed objectivity of law and thus its legitimacy.

Realism is not an entirely satisfactory explanatory tool of judicial decision making. Realism risks replacing an arbitrary formalist system with decision making that would be just as arbitrary. However, realism at least offers the hope that it would be based on better axiological bases. Unmasking the rule of law as merely a triumph of will goes only half-way to ending the theoretical basis of injustice. Revealing the hypocrisy and manipulability of a legal system does not inevitably legitimize an a-moral Weberian "value free"

10. O.W. Holmes, The Path of The Law, 10 Harv. L. Rev. 457 (1897). Holmes was, however, wrong. Law is not effective because of fear of physical force. Social sanctions are much stronger.

11. Karl Llewellyn, Some Realism about Realism-Responding to Dean Pound, 44 Harv. L. Rev. $1222(1931)$.

12. See, e.g., Robin West, Symposium: Justice, Democracy, and Humanity: A Celebration of the Work of Mark Tushnet: Reconstructing the Rule of Law, 90 GEO. L.J. 215, 218 (2001) (stating that law is the "mask of power").

13. See, e.g., Llewellyn, supra note 11 .

14. Duncan Kennedy, The Structure of Blackstone's Commentaries, 28 Buff. L. Rev. 205 (1979).

15. David Kennedy \& William Fisher, The Canon of American Legal Thought 656 (Princeton University Press 2006). 
overtly positivist alternative. Many supposed formalists, such as the late Chief Justice Rehnquist, in fact use realist methods. ${ }^{16}$ I would call persons such as Chief Justice Rehnquist "pseudo formalists." The realist critique risks giving hypocritical pseudo-formalists exactly the tools they need to deploy judicial willpower, while they pretend to observe the supposed promise of formalism that "objective" decision making will somehow guarantee substantive justice.

Not only does realism risk replicating the very problem it seeks to solve, but also it is incomplete. Realism ignores the principled use of logic and cannot explain if logic can be used in a principled manner to determine the meaning of law. Nor can realism explain how the principled use of logic can coexist with blind formalism and unprincipled pseudo-formalism. In fact, realist and formalist methods are not necessarily mutually exclusive. ${ }^{17}$ The central point that legal realism and formalism are both incomplete theories is illustrated by the E.U. courts' decisions.

Despite the flaws in realist theory, the iconoclasts and cynics are somewhat correct. Judges' decisions are results-oriented or teleologically visionary ex-post declarations (determinations) of the signification of general, vague, ambiguous a priori statements that claim to foresee all eventualities. The problem is inevitable: the greater the number of situations a statute claims to address, the more general its terms and the less de-term-inate it becomes (term as the 'last word'). However, law can be principled when it recognizes

16. See Steven G. Gey, Why is Religion Special?: Reconsidering the Accommodation of Religion Under the Religion Clauses of the First Amendment, 52 U. PitT. L. Rev. 75, 129 (1990):

The ambiguity and internal contradictions evident in the historical record do not indicate that Justice Rehnquist's Jaffree dissent is intellectually dishonest or intentionally misleading. The indeterminacy of the historical record, however, does indicate that Rehnquist's accommodationist interpretation of the establishment clause must rest on something more than the historical evidence alone; it is also based on the Chief Justice's judgment about which historical materials should be emphasized, which materials should be dismissed, and how ambiguities should be interpreted and resolved. Chief Justice Rehnquist's policy preferences lead him to make perfectly reasonable observations about the substantial role of religion in early American political society, but they also lead him to assert the less reasonable proposition that James Madison was not a strict separationist, and the even more untenable notion that Thomas Jefferson's views on church and state have little if any bearing on the meaning of the first amendment. At most, Rehnquist's originalist arguments prove that history provides support for two alternative traditions concerning the role of religion in our political culture: one separationist and one accommodationist. Although history helps to define the choices between these alternative traditions, it cannot make this choice for us.

17. A Hegelian would be pleased: the formalist thesis and the realist antithesis must lead to some synthesis. Note that a Marxist, strictly speaking, would find this dialectical relation irrelevant: the formalist/neo-formalist, realist/critical legalist debates concern the superstructure of late capitalism-i.e., the relations of production. The debate does not concern the base-i.e., the forces of production. As such, it is in Marxist terms dialectically irrelevant. This debate is not a material fact but a structural phenomenon, a reflection of the material facts. 
that fact. Legislators try, or at least claim to try, to propose a priori statements that judges then seek to apply to facts a posteriori. Of course, abuse is possible, but the possible and the necessary are two different categories. One may be honest but naïve, a formalist truth seeker, or a cynical, conniving pseudo-formalist power maximiser. But a middle way is also possible.

Pointing out the fact that "interpretative flexibility" is equivalent to legislation via the judiciary is an act of iconoclasm. Ideally, this interpretative flexibility should lead the legislature to make the hard choices that reflect the will of the people instead of delegating hot questions to unelected judges. By combining rigorous analytical terminology with holistic teleology, one can hopefully glean the best from both formalism and realism. However, combining these methods into some third theory that escapes the flaws of both realism and formalism is simply not within the scope of this article.

These lurking theoretical questions condition the interpretations of the rule/exception principle exemplified in the relationship between Articles 28 and 30. The interplay of contending interpretive methods and the theories that support them will now be exposed by using those articles of the E.C. Treaty as an example.

\section{Exposing the Mechanics of Articles 28 and $30^{18}$}

The mechanics of Article 28 are clear. Quantitative limits and measures with similar effects, whether direct or indirect, are forbidden on trade between Member States of the E.U. ${ }^{19}$ The general rule of the Community is free trade. ${ }^{20}$ Like most general rules, Article 28 is riddled with exceptions. The statutory exceptions to this general rule are found in Article 30, which simply provides that measures necessary for health reasons, the protection not only of people

18. Two preliminary notes. First, the sections of the E.C. Treaty were renumbered. Consequently, sometimes the Article will refer to "former" or "ex" to indicate the earlier numeration. Otherwise, the citations refer to current numbers. Second, there is no rule of stare decisis in international law-including E.U. law — case law is only persuasive evidence: strictly speaking, cases only determine the issues before the court between the actual parties. As a practical matter, E.U. case law is important, but it is not "written in stone." With these preliminary remarks, we can now look at the substantive law.

19. E.C. Treaty, supra note 1, arts. 28-29 read in their entirety:

Article 28

Quantitative restrictions on imports and all measures having equivalent effect shall be prohibited between Member States.

Article 29

Quantitative restrictions on exports, and all measures having equivalent effect, shall be prohibited between Member States.

20. E.C. Treaty, supra note 1, arts. 28-29. 
but also of animals and plants, are allowed as an exception to the general rule. ${ }^{21}$ As this article will explore, the interplay of the two Articles has generated several decisions that interpret the E.C. Treaty and allow or require the deployment of realist interpretative methods.

The first case we will analyze is Cassis de Dijon, ${ }^{22}$ a leading case in E.U. law. Cassis holds that Article 30 of the E.C. Treaty is to be strictly interpreted.$^{23}$ Subsequent cases limit Cassis. ${ }^{24}$ The underlying concern behind Cassis is the interplay between free trade and public health and the concern of lurking protectionism. As we shall see, a national law that looks like protectionism masquerading as a health concern will be stricken as incompatible with the E.C. Treaty. ${ }^{25}$ To reach this result, the court in Cassis and subsequent cases rely on a formalist analysis. In contrast, measures

21. E.C. Treaty, supra note 1, art. 30 reads in its entirety:

The provisions of Articles 28 and 29 shall not preclude prohibitions or restrictions on imports, exports or goods in transit justified on grounds of public morality, public policy or public security; the protection of health and life of humans, animals or plants; the protection of national treasures possessing artistic, historic or archaeological value; or the protection of industrial and commercial property. Such prohibitions or restrictions shall not, however, constitute a means of arbitrary discrimination or a disguised restriction on trade between Member States.

22. Case C-120/78, Rewe-Zentral AG v. Bundesmonopolverwaltung für Branntwein, 1979 E.C.R. I-649:

$[\mathrm{I}] \mathrm{t}$ is clear from the foregoing that the requirements relating to the minimum alcohol content of alcoholic beverages do not serve a purpose which is in the general interest and such as to take precedence over the requirements of the free movement of goods, which constitutes one of the fundamental rules of the Community.

23. Ex-Art. 30 (now Art. 28) and ex-Art. 34 (now Art. 29) have an exception-ex-Art. 36 (now Art. 30). "Art. 30 (ex-Art. 36) is to be narrowly interpreted." Andreas Ziegler, The Common Market And the Environment: Striking a Balance 76 (Difo-Druck 1995) [hereinafter Ziegler, Common Market].

24. Case C-104/74, Adriaan de Peijper, Managing Director of Centrafarm BV, 1976 E.C.R. I-613: National rules or practices which do restrict imports of pharmaceutical products or are capable of doing so are only compatible with the Treaty to the extent to which they are necessary for the effective protection of health and life of humans.

National rules or practices do not fall within the exception specified in Article 36 if the health and life of humans can be as effectively protected by measures which do not restrict intraCommunity trade so much.

In particular, Article 36 cannot be relied on to justify rules or practices which, even though they are beneficial, contain restrictions which are explained primarily by a concern to lighten the administration's burden or reduce public expenditure, unless, in the absence of the said rules or practices, this burden or expenditure clearly would exceed the limits of what can reasonably be required.

25. E.g., Case C-302/86, Comm'n v. Kingdom of Denmark, 1988 E.C.R. I-4607 [hereinafter Danish Bottles]. 
designed to serve genuine health concerns will be allowed. ${ }^{26}$ In those cases, although it is not explicitly stated, the courts rely on a realist analysis.

This presentation of the relationship between Articles 28 and Article 30, though simplified, is roughly accurate. Interestingly, it seems that the court uses realist analysis for extending the limits to free trade and a formalist analysis for upholding free trade. This is the opposite of U.S. commerce clause case law, where realism served to federalize in-state transactions. ${ }^{27}$ In the U.S., the Supreme Court has used realist jurisprudence to find "interstate commerce" even where a farmer grows grain on his own land for the consumption of his own cattle since this "affects" local trade, which in turn affects "interstate commerce." ${ }^{28}$ In all events, when the Brussels Court "stretches" the law via an unstated realist interpretation, it does not go nearly as far as the U.S. Supreme Court has in either Commerce Clause or antidiscrimination cases. ${ }^{29}$

It is worth noting that the terms of Article 30 are flexible enough to include environmental concerns. Most environmental protection is also health protection. Proper disposal of poisonous or dangerous waste is a health concern. Even the "soft" aspects of environmentalism, reducing noise levels and other types of beautification, are health measures because mental wellbeing is a part of overall health. So, there is a large domain of interpretive possibility for the Brussels Court. Fortunately, the Brussels Court has avoided the mistake of U.S. courts. The Brussels Court consistently has seen free trade as a means to the end of peace and prosperity. In contrast, unfortunately, commerce in the U.S. is not seen as a means to the end of the public good but rather as an end itself. ${ }^{30}$

Determining whether environmental issues are also health issues, and thus within the scope of Article 30, provides an example of the sort of interpretive flexibility argued for by realists. Again, the Brussels Court argues that it uses a realist interpretive scheme. However, when we look at what the court is doing, sometimes the realist scheme would apply, namely, in those instances where the law must be "stretched" to reach the right result. However, in the U.S., the "right result" is almost always wealth maximization. In contrast, in

26. E.g., Joined Cases C-304/94, C-330/94, C-342/94, and C-224/95, Criminal proceedings against Euro Tombesi, 1997 E.C.R. I-3561 [hereinafter Euro Tombesi].

27. E.g., Wickard v. Fillburn, 317 U.S. 111 (1942).

28. Id.

29. This general observation can be seen by comparing the rationales of Case C-120/78, supra note 22, and Wickard, 317 U.S. 111.

30. See generally Richard Posner, The Economics of Justice (Harvard University Press 1981). 
Europe, the right result is public health and well-being. U.S. economists mistakenly confound wealth maximization with well-being by ignoring wealth inequality. ${ }^{31}$

If one looks at environmental questions as health questions, one may, as a practical matter, be better able to determine whether an "ecological" law is just veiled protectionism or a necessary measure. Those ecological laws that improve health might more likely be found to fit within the Article 30 exception than the environmental protections that extend to aesthetic concerns such as natural beauty. Thus, the realist interpretation extending the protection of Article 30 to environmental concerns can be conditioned by the formalist inquiry as to whether those concerns touch on human health or more esoteric concerns. This article will now examine other cases that also reveal the interplay of Articles 28 and 30 to determine what restrictions on the free movement of goods are permissible.

\section{A. Waste or Wares?}

\section{Comm'n v. Kingdom of Denmark ("Danish Bottles”)}

There are several lines of interpretation that have grown out of Articles 28 and 30. We begin our analysis with Comm' $n$ v. Kingdom of Denmark, ${ }^{32}$ which is known as "Danish Bottles" because the case concerned the refundable deposit of bottles in Denmark.

The facts of Danish Bottles were undisputed. To encourage recycling, Denmark instituted a system of deposit and returns for soft drink and beer bottles. Denmark also introduced a law stating that only drinks sold within certain sizes would be permitted. The law includes a small quantitative exception to permit marketers to either try new brands on the Danish market or to allow existing brands to adjust to the new system. ${ }^{33}$ The issue in the case was whether this scheme was incompatible with Article 28 (free movement of goods) or could be considered a valid exception as one of the exceptions to Article 28 enumerated in Article 30 (health and well-being). ${ }^{34}$

31. See id. In The Economics of Justice, Posner argues that inequalities in wealth are natural, good, and the inevitable result of merit or lack thereof. Also, he posits that the common law reflects market transactions. However, the economic results he notes are not inevitable; they are the consequence of a certain social organization of production. Moreover, I think that those outcomes are often unfair.

32. Danish Bottles, supra note 25.

33. Id. $\mid 3$.

34. Id. ๆๆ 8-11. 
The scheme was found to be incompatible with Article 28 because the exception in Article 30 did not apply. ${ }^{35}$ The ECJ held that reasonable restrictions on waste processing that do not actually or potentially block free movement of goods are permissible. However, environmental intervention must employ the least restrictive means. ${ }^{36}$ Thus, under Article 30, the ECJ applies a proportionality test. ${ }^{37}$ To a U.S. lawyer, this test looks similar to U.S. constitutional "means-end" testing. ${ }^{38}$ The text of Articles 28 and 30, however, do not contain "means-end" terminology. Indeed, the court's determination, while reasonable, does not seem to rely on the explicit text. Rather, the court relies on an extensive interpretation akin to that applied by legal realists. ${ }^{39}$

Applying the rule provided by the court to the facts of the case, the Commission struck the Danish law as an illegal quantitative restriction on the free movement of goods. ${ }^{40}$ The court noted that distinguishing between types of bottles and establishing a system of returns was not per se illegitimate. ${ }^{41}$ The court did not accuse the Danish legislature of intending to discriminate. However, the court found that the law had a discriminatory effect on trade and, thus, was incompatible with the E.C. Treaty. ${ }^{42}$ U.S. scholars would instantly recognize that "effects" analysis as one of the hallmarks of realist legal interpretation. ${ }^{43}$ Thus, a system of bottle-returns somehow would have to accommodate (by implication) foreign bottles ${ }^{44}$ to avoid a discriminatory effect. What applies to one field of recycling probably applies to others as well (batteries, paper, glass, and metals). The recycling system itself was not impermissible. The impermissible act was the fact that the system of recycling resulted, de facto, in a restriction on imports of bottles from other states. ${ }^{45}$

Although the facts and ruling in Danish Bottles are fairly clear, one also should note that to reach the ruling the court used several doctrinal maneuvers.

35. Id. 922.

36. Danish Bottles, supra note 25; Ziegler, Common Market, supra note 23, at 117.

37. Ziegler, COMMON MARKet, supra note 23, at 114.

38. Danish Bottles, supra note 25, $\mid 6$ ("If a Member State has a choice between various measures for achieving the same aim, it should choose the means which least restricts the free movement of goods.").

39. Id. I 10 ("The Commission submits that the Danish rules are contrary to the principle of proportionality in so far as the aim of the protection of the environment may be achieved by means less restrictive of intra-Community trade.").

40. Id. $\uparrow 22$.

41. $\quad I d$. at 98 .

42. Id. at 9 - 20-21.

43. See, e.g., Blake D. Morant, The Teachings of Dr. Martin Luther King, Jr. and Contract Theory: An Intriguing Comparison, 50 Ala. L. Rev. 63, 72 n.39 (1998).

44. Danish Bottles, supra note 25, 9 ๆ 21-22.

45. Id. at 921 . 
By examining those maneuvers and comparing the competing legal theories that justify or deny those maneuvers, one will be better able to determine how similar future cases will be decided.

Danish Bottles provides the principle that Article 30 can be derogated from the four essential objectives of the Community and as a corollary, that health is an essential objective of the Community. Thus, the holding in Danish Bottles is similar to Cassis. One can find a rule of law that is formally valid: that a state may only derogate from Article 28 (ex-Art. 30) when such derogation is a proportional means to a legitimate end. ${ }^{46}$ In fact, proportionality and means-end testing ${ }^{47}$ offer enough margin of interpretation such that, by turning to a realist interpretation, judges can strike or uphold almost any state act and remain formally true to the texts of the E.C. Treaty and to their own prior interpretation. Arbitrary judicial power is mitigated by the court contextualizing its interpretation and justifying it according to the teleology of "an ever closer union" of the European people. Allowing the European people to enjoy peaceful trade, a single market, and high standards of well-being are obviously legitimating ends. Despite the realist critique, the court does seem faithful to those goals. Therefore, the legal realist thesis is, like most descriptions of reality (including this one), only partial. Both the formalist and realist description are only partially correct. The court cannot interpret its formal terms in an objective method such that the decision is "inevitable." However, the court cannot, or at least does not, entirely twist the law to suit its own purpose. Rather, the court seeks to achieve the goals of the text of the E.C. Treaty and uses that text to underpin its decisions. Fortunately, in this author's opinion, the court reaches the right results. However, it does so without acknowledging the interpretive models that seem to shape its decision and, therefore, cannot help one to synthesize a better, more inclusive model. $^{48}$

What about the court's "effects" analysis? The effects-based reasoning raises the issue of judicial voluntarism. Again, this reasoning is saved by the telos of the E.C. Treaty. ${ }^{49}$ Both intent and effects are justifications for ignoring Article 30. Thus, only the general presumption of conformity with the law of the Member State and of the European Union would allow the discriminatory

46. Id. at 96 .

47. Means-end testing is a well known doctrinal element of U.S. constitutional law. E.g., M'Culloch v. Maryland, 17 U.S. 316, 421 (1819).

48. The words "realism" or "realist" appear nowhere in Danish Bottles.

49. Danish Bottles, supra note 25, 9 ๆ 8, 12,13, and 21 . 
law to avoid sanction. ${ }^{50}$ However, that presumption would not be strong enough since the very purpose of the Union is to secure a single market to build peace and prosperity. ${ }^{51}$

How should Denmark have protected its roadside from waste bottles? If Denmark had taxed all bottle sales, and used the revenue from that tax to fund the return program, the law would probably have been upheld. A voluntary return scheme may also have been effective. Or, a purely internal sales tax would probably be seen as non-discriminatory. Another alternative would have been to levy a landfill tax or user-fee on all bottles, foreign and domestic.

However, shifting the tax levy from the point of sale to the point of disposal also raises problems. A state could impose a heavy landfill tax not to raise revenue to fund recycling but rather to discourage waste disposal on its soil. That would be against the purposes of the single market and incompatible with the E.C. Treaty. But how could the court distinguish between: 1) landfill taxes that are essentially fees levied to run the landfill from landfill taxes used to encourage recycling; and 2) landfill taxes that have the effect or intent to essentially export landfills and incinerators to poorer lands? This author would recommend comparing the rates of the fee both with the service provided and with rates charged for similar services elsewhere in the Community. The inquiry also should examine whether environmental programs, such as recycling, exist as part of a common scheme and whether they allocate tax revenues generated from the fee system to recycling or other environmental programs. Thus, the most survivable national law would exact a user fee for landfill similar to fees in neighboring lands and not more expensive than the cost of the service provided. To the extent that the fee generates funds, those funds would be best earmarked and allocated for funding the landfill or incinerator and for promoting recycling. The least survivable law would allocate resources to the general tax fund, not introduce any program of recycling, and charge significantly more than the worth of the

50. Walter van Gerven, Bridging the Gap Between Community and National Laws: Towards a Principle of Homogeneity in the Field of Legal Remedies?, 32 Cоммоn Mкт. L. Rev. 679, 687-89 (1995).

51. E.C. Treaty, supra note 1, art. 2 reads in its entirety:

The Community shall have as its task, by establishing a common market and an economic and monetary union and by implementing common policies or activities referred to in Articles 3 and 4, to promote throughout the Community a harmonious, balanced and sustainable development of economic activities, a high level of employment and of social protection, equality between men and women, sustainable and non-inflationary growth, a high degree of competitiveness and convergence of economic performance, a high level of protection and improvement of the quality of the environment, the raising of the standard of living and quality of life, and economic and social cohesion and solidarity among Member States. 
service or the rate charged by neighboring states including non-Member States.

Political issues, such as Denmark being a "reluctant European," may also be taken into account by using a realist interpretative schema. The court in Danish Bottles may have sought to make an example of Denmark by chastising it. However, it is possible to determine, in a principled manner, policies that would be acceptable to the Union and that would serve the interests of the people of Denmark. Again, this illustrates why the realist position, like that of the formalists and neo-formalists, is only partially correct.

\section{Walloon Waste ${ }^{52}$}

We have just briefly outlined the question of waste disposal. What about waste export? An interesting oversight in the decision in Danish Bottles was the fact that the court did not first inquire whether the traffic in deposit and returns was "goods." 53 While the court has defined "goods," never even defined how waste is a type of "goods." "The court does state that whether or not waste is returnable is irrelevant to waste's status as a "good." In Walloon Waste, the court determined that "waste" is in fact a "good" ${ }^{57}$ for the purposes of the E.C. Treaty and that states may not ban the import or export of wastes. ${ }^{58}$ This example of judicial interpretation supports a realist interpretation of the court's efforts to maximize its own power before the Member States. The fact that it regards waste material as a "good" is an example of a lurking realist jurisprudence in the ECJ's decisions. This is similar to, though not quite as extreme, the U.S. Supreme Court regarding wheat grown and consumed on a farm as "interstate commerce." In both Waste].

52. Case C-2/90, Comm'n v. Kingdom of Belgium, 1992 E.C.R. I-4431 [hereinafter Walloon

53. Andreas Ziegler, Trade and Environmental Law in the European Community 33 (Oxford University Press 1997) [hereinafter Ziegler, Trade and Environmental Law].

54. Walter Frenz, Europaisches Umweltrecht 222 (Verlag Beck 1997); Christian Zacker, Abfall Im Gemeinschaftlichen Umweltrecht 170 (Duncker and Humboldt 1997).

55. Ziegler, Trade and EnVironmental LaW, supra note 53, at 33-35.

56. ZACKER, supra note 54, at 172 (citing Case C-155/91 Comm'n of the European Communities v. Council of European Communities, 1993 E.C.R. I-939).

57. Walloon Waste, supra note 52, \23.

58. Id. at 921.

59. Wickard, 317 U.S. at 127-29. 
cases, the paradoxical interpretation is justified only by a teleology of continental free trade.

The failure to define waste, and demonstrate that waste was in fact a good in Danish Bottles, somewhat can be defended by the principle of judicial economy. Courts, in a desire to protect their own legitimacy and limit their workload, will answer only what they must. Yet, Walloon Waste avoids defining goods and does not explain why waste should be considered a good. Thus, one could accuse the court of ignoring the threshold issue (whether wastes are goods) and using conclusory language to reach the answer it desired. ${ }^{60}$ The court could reach this result using either formalism or realism! Which is it using? Both. The court never says it is using either formalism or realism. However, when it restricts application of a legal rule, the court acts like a formalist, and when it extends the legal rule, it acts like a realist. When a given scientific theory is inadequate to explain an observed phenomena, the theory must be either extended or rejected to cover the new phenomenon.

The ECJ's non-analysis of whether waste, that is not being bought or sold, is a "good" is revealing. It shows how judges can duck hard questions, and demonstrates the more radical thesis of legal realism-law is merely the mask of power. It is clear that waste products, unless recycled and resold, are not "goods" in factual market terms ${ }^{61}{ }^{1}$ However, the traffic in waste products, which are sent to landfills, incinerators, and recycling centers, would be subject to the free movement of services ${ }^{62}$ or the free establishment clauses. The court's logical error might be dismissed as a formal flaw, mischaracterizing as trade in "goods" what is actually trade in "services." However, that error has no substantive impact and is thus non-prejudicial: The court's mere formal error is irrelevant. Formal manipulability does not necessarily lead to unfair outcomes. The same results could have been reached through the free movement of services and the free establishment clauses ${ }^{63}$ without a need to characterize waste as "goods." Additionally, perhaps lurking beneath the surface of Walloon Waste is the sort of "effects" analysis found in Danish Bottles and similar to constitutional interpretation of the U.S. Commerce Clause. By characterizing what is obviously not a good as "goods"

60. Ziegler, Trade ANd EnVIRONMENTAL LAW, supra note 53, at 35.

61. More accurately, wastes are not goods but their disposal is a service. Thus, rather than being subject to the provisions on free movement of goods they should be considered a subject of free movement of services. ZACKER, supra note 54, at 184.

62. "Einige Autoren sind der Meinung, daß Abfälle sowohl der Warenverkehrs als auch der Dienstleistungsfreiheit unterfallen können." ZACKER, supra note 54, at 176.

63. Right of establishment, E.C. Treaty, supra note 1, arts. 43-48; Free movement of services, E.C. Treaty, supra note 1, arts. 3(1)(c), 14(2), and 49-55. 
for the purposes of the E.C. Treaty, the court opens the possibility of extending the Union's power to realms that are not facially in the terms of the E.C. Treaty or even in the minds of the framers of the E.C. Treaty. What at first seems only a quirky misinterpretation suddenly takes on a "federalism" dimension reminiscent of Wickard v. Filburn. ${ }^{64}$ This author would like to suggest that, when the Brussels Court extends its power, it will do so using realist jurisprudence. However, when it restricts the power of the Member States, it will do using formalist jurisprudence. This does not mean that the court is acting unjustly or without principle, but it does mean that a new theory that can explain this apparent contradiction should be developed.

The court makes the factual error of identifying waste as goods. Does it also incorrectly define waste? The definition of "waste" is somewhat ambiguous ${ }^{65}$ Waste is not defined in the E.C. Treaty, but in the secondary legislation $^{66}$ and case law. So, discussing one topic, namely waste, raises questions of primary, ${ }^{67}$ secondary ${ }^{68}$ national, ${ }^{69}$ and community law. In sum, the field of E.C. waste law is a mess. "Waste" and "goods" are in fact mirrors. Each is part of the economic cycle, and one implies the other. Waste, a bad, is transformed into its opposite, a good, via recycling. That is the economic cycle. However, the economic facts are not the basis of the legal classification, and the facts refute the thesis of law and economics, which holds that law is a reflection of economic processes. In factual market terms, wastes are "bads," the very opposite of goods.

In Walloon Waste, the main statutory analysis focused on secondary law sources. ${ }^{70}$ However, while the main statutory interpretation of the definition of "waste" dealt with secondary law sources, at least one commentator argues that Walloon Waste stands for the general principle that environmental protection and free trade are incompatible and that waste is a good that enjoys free movement. ${ }^{71}$ Thus, the packaging used to furnish a good is also a good and is subject to the free movement provisions including the Article 30 (ex-

64. Wickard, 317 U.S. 111.

65. The definition of waste is ambiguous. Alke Schmidt, Transboundary movements of waste under EC law: The Emerging Regulatory Framework, 4 J. EnV’T L. 57, 59 (1992) (U.K.). (EU)).

66. See the new codified waste Framework Directive (Directive 2006/12/EC, 2006 O.J. (L 114) 9

67. Danish Bottles, supra note 25.

68. Euro Tombesi, supra note 26.

69. Id.

70. Notably, Council Directive 84/631/EEC, 1984 O.J. (L 326) 31 (EC).

71. Ziegler, Common Market, supra note 23; Walloon Waste, supra note 52. 
Art. 36) exceptions. ${ }^{72}$ That analysis, if correct, would undermine the source principle that waste should be treated as close to the point of its production as possible.

\section{B. Recycling-Oil Cases: Inter Huiles; Brûleurs d'Huiles Usagées}

Wastes to be disposed of (generally by incineration or in landfills) are goods and enjoy the freedom of movement under the E.C. Treaty. Recycled wastes, are in fact also treated as goods. ${ }^{73}$ Thus, according to Inter-Huiles, a state cannot organize a system for the collection and disposal of waste oils within its territory in such a way as to prohibit exports to an authorized disposal or regenerating undertaking in another Member State. ${ }^{74}$

The holding of Inter-Huiles must be reconciled with another oil recycling case, Brûleurs d'Huiles Usagées. ${ }^{75}$ According to Huiles Usagées, national measures must be reasonable means ${ }^{76}$ to permissible ends. ${ }^{77}$ However, these means must be the least restrictive means possible, ${ }^{78}$ although environmental protection was recognized to be an essential goal of the Community. ${ }^{79}$

Just as we earlier saw a parallel to "means-end" review, we also see another parallel in Brûleurs d'Huiles Usagées. Similarly, the U.S. federal government's ability to pre-empt the states as to concurrent powers is mirrored in E.U. law. ${ }^{80}$ However, mirrors not only reflect, they also reverse. According to the doctrine of subsidiarity, a general principle of Community law, when the Community and the Member States have joint competence, the Member States should be given priority. ${ }^{81}$ Both systems are "flexible" or

72. Ziegler, COMMON MARKeT, supra note 23, at 44-45.

73. See Danish Bottles, supra note 25.

74. Case C-172/82, Syndicat National des Fabricants Raffineurs d'Huile de Graissage v. Groupement d'ilnteret Economique Inter-Huiles, 1983 E.C.R. I-555, 567-68.

75. Case C-240/83, Procureur de la Republique v. Association de Defense des Brûleurs d'Huiles Usagées, 1985 E.C.R. I-531.

76. Id.

77. Id.

78. Danish Bottles, supra note 25; ZIEGLER, CoMmon MARKET, supra note 23, at 117.

79. "The Directive must be seen in the perspective of environmental protection, which is one of the Community's essential objectives." Case C-240/83, supra note 75, ๆ 13. See also Craig/BurC, EC LAw 642-43 (Clarendon Press 1995).

80. See, e.g., Joined Cases T-366/03 \& T-253/04, Land Oberösterreich and Republic of Austria v. Commission, 2005 E.C.R. I-4005.

81. E.C. Treaty, supra note 1 , art. 5 reads in its entirety:

Article 5

The Community shall act within the limits of the powers conferred upon it by this Treaty and of the objectives assigned to it therein. 
"manipulable." A restrictive interpretation of environmental law would focus on the means, which must be the least restrictive possible. ${ }^{82}$ On the other hand, the judge could also downplay the means and focus on the end. Environmental goals are not only a permissible goal, they are in fact an essential end ${ }^{83}$ Of course, the means must be "reasonable." The result of this realist balancing act is a judicial decision according to the will of the judges. Such a decision can be principled but only if properly contextualized (considering all facts in the case) and directed according to the law's finality (its objective) through teleological interpretation. ${ }^{84}$

Both Interhuiles and Brûleurs d'Huiles Usagées seem very similar yet reach different outcomes. That divergence justifies skepticism toward legal logic. A juridical analysis that wishes to be complete must also analyze political factors that influence the court, and thus escapes the formal language of the positive law described overtly in the decisions of the court. Politically speaking, the fact that the anti-environmental line of cases represented by Danish Bottles and Danish Autos ${ }^{85}$ was immediately qualified, indicates that the court went too far in chastising the smaller eurosceptics and then felt obliged to mollify them, using "good cop," "bad cop" writ large. Such political speculations cannot be proven but should be considered in order to complete our understanding of the court's decision-making process.

\section{Criminal Cases Involving the Free Movement of Waste-goods}

\section{Waste Dumping Criminal Proceedings against Matteo Peralta ${ }^{86}$}

We have just looked at civil remedies to environmental problems, which we have found, with qualification, can be compatible with the E.U. and its goals. What criminal remedies are possible? What limits may a member state

\footnotetext{
In areas which do not fall within its exclusive competence, the Community shall take action, in accordance with the principle of subsidiarity, only if and in so far as the objectives of the proposed action cannot be sufficiently achieved by the Member States and can therefore, by reason of the scale or effects of the proposed action, be better achieved by the Community.

Any action by the Community shall not go beyond what is necessary to achieve the objectives of this Treaty.

82. Danish Bottles, supra note 25; Ziegler, Common MARKet, supra note 23, at 117.

83. CRAIG/BurC, supra note 79, 642-43.

84. Aristotle, Nicomachean Ethics Book 5 (Roger Crisp trans., Cambridge University Press

85. Case C-47/88, Comm'n v. Denmark, 1990 E.C.R. I-4509.

86. Case C-379/92, Criminal Proceedings against Matteo Peralta, 1994 E.C.R. I-3453.
} 2000). 
place on toxic dumping? Because the court has determined waste is a good, whenever a member state tries to regulate waste, it is potentially restraining the free movement of "goods." To determine what limits the E.U. treaty imposes on its member state's penal laws in the realm of environmental law, one must look at Criminal Proceedings against Matteo Peralta. ${ }^{87}$

Matteo Peralta, the Italian Captain of an Italian flagged vessel, dumped highly toxic caustic soda out of his ship's bulkheads into the Mediterranean Sea outside of Italian territorial waters. ${ }^{88}$ Italy had a law criminalizing dumping of toxic wastes on the high seas by Italian flagged vessels. ${ }^{89}$ The ECJ upheld Italy's law because it did not refer to the source of the wastes and did not have as an object the regulation of trade between the states. ${ }^{90}$ The court also stated that any effect on trade between Member States was too indirect and uncertain to hinder trade between Member States. ${ }^{91}$ That is exactly the opposite of the U.S. Commerce Clause effects-based jurisprudence. In the U.S., remote effects can, and often do, amount to interference with "interstate commerce" 92 via a cumulative effects analysis. Community law does not prohibit a state from prohibiting a vessel from dumping toxins into its own or international waters. ${ }^{93}$ Thus, at least in this instance, the ECJ is unwilling to limit the penal jurisdiction of the Member States. But what will happen as the E.U. develops its own penal law? There are sensible reasons to develop a community law of the sea for the Member States since that will avoid the traditional disputes over fisheries, territoriality, and pollution while reducing transaction costs over the long term. This is a potential area for future E.U. legal development.

\section{Criminal Proceedings v. Euro Tombesi}

Criminal remedies are also available against improper recycling. In Euro Tombesi ${ }^{94}$ the court determined that waste (subject to Union directives and regulations) can become wares (subject to the E.C. Treaty). Waste does include objects to be recycled that are legally and economically goods. ${ }^{95}$ The

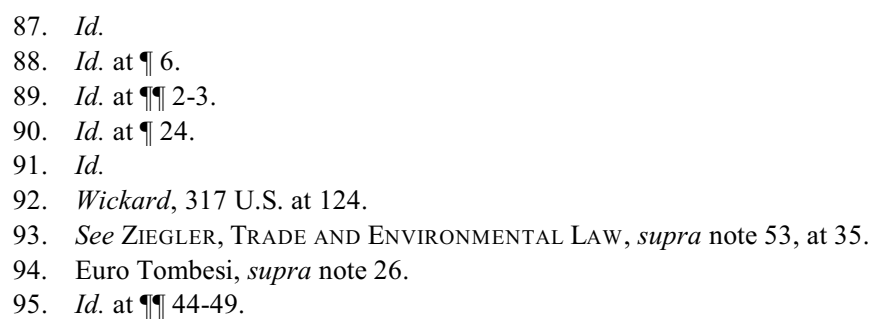


facts of this case were close to the Article 28 (ex-30) and Article 30 (ex-36) combination: A company recycling waste into goods was found criminally liable for its wrongful act. However, since the goods did not appear to have crossed the Italian frontier, the cases were not considered under Articles 28 and 30, but rather under directives dealing with waste reprocessing leading to similar results. The limitation on commerce to attain the genuine interest in public health was consistent with the E.C. Treaty.

\section{Other Remedies to Pollution}

Restriction on free movement of goods is one method of protecting the well-being and health of the people. However, it is, essentially, presumptively illegal and only exceptionally allowed. Thus, E.U. Member States also look to other methods of environmental protection that are less likely to contravene the E.C. Treaty. Subsidization, taxation, and labeling may also be used to protect the environment of Member States. While in theory these are also subject to Article 28, in practice they are less directly relevant to the free movement of goods, and thus can be used (subject to other limits in the E.C. Treaty) to implement environmental policy more easily.

\section{A. Subsidization}

One solution to pollution is to establish environmental protection funds, paid for by polluting activities. Such funding mechanisms can be in conflict with the E.C. Treaty where they act to discriminate against foreign goods: "an environmental fund for the support of domestic producers only, but financed by a levy on both domestic and imported goods would . . . fall under the prohibition in Article 12." ${ }^{\prime 96}$ Further, such refunds may raise problems under the specific treaty provisions on subsidies." ${ }^{.97}$ However, careful drafting can avoid this problem: the fee charged must apply to both domestic and foreign goods and subsidizations must be made available to domestic and foreign companies on an equal basis.

96. E.C. Treaty, supra note 1, art. 12 ("Within the scope of application of this Treaty, and without prejudice to any special provisions contained therein, any discrimination on grounds of nationality shall be prohibited.").

97. Ziegler, COMmon MARKet, supra note 23. 


\section{B. Taxes}

Subventions are not the only solution to pollution-so are taxes. The Article 30 (ex-Art. 36) exemptions could be applied to tax schemes for environmental purposes. Thus, taxes on pollution-even where touching free movement of goods and services - are not unthinkable. ${ }^{98}$ However, while ecological customs duties are not necessarily impossible they are difficult to implement. This is partly because the distinction between internal taxation and customs duties is a fine one. ${ }^{99}$ Simply imposing tax on a good not produced by a member state will not be considered a restriction of the free movement of goods. ${ }^{100}$ However, where that tax distinguishes between the domestic market and the foreign market through a tax reduction for resale - even though this avoids double taxation - the tax will be seen as opposed to the free movement of goods provisions of Article 30 (ex-Art. 36). ${ }^{101}$

\section{Labeling}

Another alternative means of regulating waste is through labeling. Labels provide a uniform standard. They simply state that a product is made with environmentally friendly or unfriendly processes, and thus encourage consumption of one over the other. One problem with labeling is that it is uncertain whether ecological labels are a matter of exclusive Union competence or whether labeling is of shared competence. ${ }^{102}$ The present practice, however, is that both the Member States and the E.U. can use product labels to indicate to consumers products that are environmentally friendly.

\section{CONCLUSION}

In terms of positive law, the conclusions of this paper are rather straightforward. The free movement of goods is not an absolute right. Rather,

98. Walter Frenz, Umweltschutz durch Zölle ist denkbar ("Environmental protection through tolls is conceivable") EUROPÄISCHES UMWELTRECHT 222 (Verlag Beck 1997). 1994).

99. Paul Farmer \& Richard Lyal, EC Tax LaW 4 (F.G. Jacobs ed., Oxford University Press

100. Case C-47/88, supra note 85 , 125.

101. Id. at 31 .

102. Ludwig Kramer \& Pascale Kromak, Droit Communautaire de L'environnement, 2-3 RevUE JURIDIQUE DE L'ENVIRONNEMENT 221-23 (1994) (Fr.). 
it is conditioned on public health and well-being. ${ }^{103}$ Recycling systems, limitations on waste dumping, criminal sanctions, product labeling, taxation and subsidization are all possible environmental policies that may be implemented by the Member States provided that they respect the freedom of movement of goods. Environmental protection that is not tailored to consider the free movement of goods may be stricken (e.g., Danish Bottles). At the same time, it may be upheld.

The more interesting question is how these competing objectives - broadly speaking, free trade and environmental protection - are balanced against each other. At times, the ECJ resorts to realism, for example, in defining "goods" to include "waste" even though waste is neither sold nor bought. Another realist tactic would be to look to the discriminatory effect instead of the discriminatory intent of the legislature, as would the inquiry into whether the law potentially restrains trade versus asking whether the statutory law in fact restrains trade. At other times, the court appears to engage in formalism via a careful formalist parsing of legal terms syntactically to determine a semantic interpretation of the law based on canons of construction looking for legislative intent. This author is of the opinion that the court's arguments from teleology (policy goals) and the courts means-end analysis of proportionality are in fact neo-formal methods. However, one could argue that they are policy analyses-i.e., a part of realist interest balancing.

The ECJ principally, but not exclusively, seems to rely on realist methods of interpretation to further the purposes of the Community, it does not seem, at least in this limited study, to admit that it is relying on realist arguments and methods. Instead, the court leaves open the possibility of using formal logic to parse and interpret the text of the E.C. Treaty because of legal parsimony and judicial economy. When the court does rely on formalist methods, it is usually to restrict the Community's intervention in the law of the Member States. Similarly, the court usually uses realism to extend the Community's intervention in the law of the Member States. However, it does not choose either theory to the exclusion of the other or even consciously announce that it is applying one theory or the other. This is a prudent choice because realism and formalism are both incomplete legal theories and do not explain all observed phenomena. Unfortunately, developing a model to compensate for these weaknesses is beyond the scope of a brief law review article. That is left as a task for future research. 